\title{
STRATEGY FOR BUILDING COMMUNITY-RELIANCE IN MANAGING AND UTILIZING COMMUNITY FORESTS THROUGH THE POLICY OF COMMUNITY FORESTS DEVELOPMENT
}

\author{
Benjamin*, Hidayati Dewi Ayu \\ Sociology Departement, Faculty of Social and Political Sciences, \\ University of Lampung, Indonesia \\ Rosalia Feni \\ Government Studies Departement, Faculty of Social and Political Sciences, \\ University of Lampung, Indonesia \\ Kagungan Dian \\ Public Administration Departement, Faculty of Social and Political Sciences, \\ University of Lampung, Indonesia \\ *E-mail: bensosunila@gmail.com
}

\begin{abstract}
The objective of this research is to provide policy recommendation with regard to strategy formulation for the development of community forests. The policy recommendation aims to improve local people's economy, to alleviate poverty and to achieve community-reliance through the utilization of community forest programs. This study is also aimed to strengthen roles and functions of various institutions to be synergized in empowerment activities in line with the jurisdiction of rights for management and utilization of community forest. This research used descriptive qualitative approach. Data was collected from Tanggamus Regency in Lampung Province of Indonesia through interviews. Secondary data was also obtained from related sources: literature and government regulations. This study found that the implementation of community forest policy is merely based on the government regulation. Another finding is that empowerment practices undertaken in the community forest is still lack of the involement of stakeholders. In addition, there is a positive impact in the practice of community forest which can be seen from the level of public awareness to the forest and in planting crops. Therefore, this research suggests that: first, there is the need of policy to overcome bureaucratic system in applying the community forest management permits; second, it needs a new formulation of budget to facilitate the community in the application of the community forest management.
\end{abstract}

\section{KEY WORDS}

Community, forest, policy, reliance.

Forest is one of national development capitals which benefits people's lives and livelihoods. But, the destruction of forests as a result of a rapid utilization of forests which is not accompanied by the application of norms in a juridical way is very problematic. The fact is that the destruction of forests is againts current forest management in preserving and utilizing nature for prosperity of people. More specifically, in the context of Lampung Province in Indonesia, forest destruction has reached at around 53 percent of national forest in Lampung. The conservation and development of forest as natural environment can be obtained, if people who live in the forest can protect and manage the forest in a good way. It is undeniable that forest destruction in Lampung Province, especially in Tanggamus Regency is caused by exploitation of the forest by people around the forest who deliberately exploit the ecological functions of the forest without restoring the forest. Data from a NGO called Watala and from the National Forest Protection Unit at Tanggamus Regency in 2016 shows that more than 7,000 encroachers have penetrated the protected forest through illegal 
logging and looting of forest resources in an area called registering 30 at Tanggamus Mountain resulting the damage of 7,500 hectares or $79.54 \%$ of protected forests. Another problem is that the technical implementation of community forest has not been widely known to the public or insufficient information of regulations related to the implementation of community forestry at the village level. More problematic is where encroachers work for people who invest or support them financially to exploit protected forests, so that the benefit from forest exploitation will be shared among them based on agreement. Sometimes, people who invest money to encroachers are backed up by unscrupulous authorities.

The empowerment approach can be done with five ways, namely: possibility, strengthening, protection, support, and maintenance (Anwas, 2014). One of the empowerment approaches is the aspect of strengthening knowledge and ability of the community in solving problems and fulfilling their needs. Empowerment should be able to develop all capabilities and the confidence of the community which can support their sovereignty. Thus, there is the need for a policy aimed to empower the community in regard to the community forest. Community forest itself is a state/national forest whose utilization is aimed for empowering local communities, as described in the Minister of Forestry Regulation No.P.13/Menhut-II/ 2011. Community forest policies allow communities to manage some of forest resources with a specific regulation. Thus, community empowerment is seen as an effort to improve the ability and the sovereignty of the community (Bartlett, 2008). As a result, the community can optimally and fairly get benefits from forest resources through capacity building and access granting in the framework of community welfare. Moreover, the implementation of community forestry policy through local community empowerment starts from socialization and facilitation activities including the selection of methods and tools as well as strengthening the institutional function of the group of community forestry peasant. All these initial activities should be synergized to obtain the benefits of forest resources optimally and fairly without damaging forest functions and these also do not conflict with sustainable forest principles through the regulation of rights on the management and utilization of community forests. The activities include capacity building as well as access provision in the context of improving the welfare of local communities.

Furthermore, the important of this research is that the existence of forestry policy provides an opportunity for people to participate in managing forests or in benefitting forest for communities around the forests. This can be done by granting access rights to the community and by placing the community as the main actors for the forest development and management. The empowerment program needs people who live in and around the forest such as small groups' people consisting of several families, people who formed tribes or villages where they interact strongly between social, economic and cultural life of the community with the forest environment. According to Sutaryono (2008), rural communities around the forest are a society with relatively low in level of education, welfare, initiation and creativity. There is culture of acceptance with current situation and fatalist attitude make people always to be subordinated of systems, causing difficulties in the empowerment process. The typical of forest community is low in economic and educational levels which has a tendency to meet its needs depending on forest resources. Low levels of education make them less likely to be skilled at activities, let alone on issues they have never heard of and ignorance.

The lack of knowledge of people around the forest causes poor on managing community forests and people tend to exploit the potential of forest resources unfavorably, taking the forest resources by way of encroaching. These activities impact on a negative meaning for the forest, cutting down forest trees or plants without repairing the forest. Given the low level of knowledge for forest management, it also impacts the way people manage forests unproperly. Encroaches' activities on forests result the forest destruction, although forest as natural environment needs to be preserved. Environment is one of the important elements for the life of living things: human beings, animals and plants. Environment becomes the determinant of how living things continue to grow and it becomes a place for them to live. 
Research findings from Rosalia, et al (2016) found that the implementation of community forest policy in Tanggamus Regency can be said very disappointing where the technical implementation of community forest has not been widely known by the community and there is less intensive socialization about community forest, especially on technical implementation problems. These situations result in less understanding about rights and obligations for the management and utilization of community forests. There is also a jealousy among communities between who already have a community forestry permit and who have not received the permit. In addition, research by Rosalia, et al (2016) found that there is less effective rules indicated the existence of immoral apparatus to back up encroachers to seek individual profit by giving financial support to them to exploit the forests. Thus, this study aims to provide policy recommendation in relation to several aspects as follows: (a) economic role of the community. This means that there is the need to improve the economic role of the community through the utilization of community forest by groups of community forestry farmer in order to create food security. (b) support from public. This means that there is the need to strengthen institutions, especially farmer groups which are relevant in the process of conducting empowerment activities in forest management with balancing ecological functions and subsistence social functions of local communities.

In conjunction with Community Forestry stated in the Decree of the Minister of Forestry Number: P.37/Menhut-II/2007) juncto Regulation of the Minister of Forestry of the Republic of Indonesia No.P.13/Menhut-II/2010, state/national forest under forest management system aims to empower or enhance economic and cultural values as well as to provide benefits to local communities without disrupting its main functions. Moreover, based on data from Watala and World Agroforestry (2005), most areas in Lampung Province have implemented Community Forestry policies since 1998. Bandar Lampung and South Lampung areas, called register 19 Gunung Betung, are the first areas in implementing Community Forest policies. Generally, the process of community forest undertaken by communities is relatively similar, starting from forming community forest groups, followed by deciding areas, and creating and submitting proposals for a permit. The legal standing of the process is related to Minister of Forestry Regulation No P.37/Menhut-II/2007 on Community Forest (Hkm) along with Minister of Forestry Regulation No.P.13/Menhut-II/ 2010. The form of initiatives in supporting the development of community forest either by the government at regency or by communities/forest management groups in 8 regencies is relatively the same. They are socialization of policy, guidance, provision of assistance of seeds Multi Purpose Tree Species (MPTS) to community groups and giving license to manage the forests.

Table 1 - Form of Innitiatives in Supporting the Implementation of Community Forestry

\begin{tabular}{|c|c|c|}
\hline $\mathrm{n} / \mathrm{n}$ & Form of Innitiatives & \\
\hline Regency/City & Government/Forestry & Groups \\
\hline Bandar Lampung & $\begin{array}{l}\text { - Policy Socialization } \\
\text { - Guidance and Assistancy }\end{array}$ & $\begin{array}{l}\text { Forming Groups } \\
\text { Group Meetings } \\
\text { Permit Arrangement }\end{array}$ \\
\hline Lampung Selatan & $\begin{array}{l}\text { - Policy Socialization } \\
\text { - Seedling Support } \\
\text { - Monitoring Progress of the Group } \\
\text { - Giving Permits }\end{array}$ & $\begin{array}{l}\text { Forming Groups } \\
\text { Planting Forest } \\
\text { Education } \\
\text { Propossing Permit } \\
\text { Group Meetings }\end{array}$ \\
\hline Tanggamus & $\begin{array}{l}\text { - Policy Socialization } \\
\text { - Groups Monitoring } \\
\text { - Granting Permits to the Community } \\
\text { - Data Arrangements }\end{array}$ & $\begin{array}{l}\text { Forming Groups } \\
\text { Proposing Field Facilitators } \\
\text { Proposing Permits } \\
\text { Group Meetings }\end{array}$ \\
\hline Lampung Tengah & $\begin{array}{l}\text { - Policy Socialization } \\
\text { - Group Assistance } \\
\text { - Establishment of Task Force Team for Forest } \\
\text { Protection and Field Facilitators } \\
\text { - Data Arrangement } \\
\text { - Seedling Support }\end{array}$ & $\begin{array}{l}\text { Forming Groups } \\
\text { Setting Up Group Rules } \\
\text { Seting Up Workplan for Forest management } \\
\text { Propossing Permit } \\
\text { Propossing Field Facilitators } \\
\text { Group Meetings } \\
\text { Propossing New Group } \\
\text { Propossing New Permits } \\
\text { Comparative Field Study }\end{array}$ \\
\hline
\end{tabular}

Source: Watala Lampung. 
According to Anwas (2014), the concept of empowerment itself evolves from the reality of helpless individuals or powerles societies. Powerlessness has weaknesses in various aspects, such as knowledge, experience, attitudes, skills, business capital, networking, passion, hard work, persistence, etc. Those weaknesses lead to dependence, helplessness and poverty. Empowerment itself is a concept related to power. The term power is often identical to the individuals' ability to make them independent gaining their needs as well as their ability to govern theirselves, to organize others as individuals or groups/organizations, regardless of the needs, potentials, or desires of others. Empowerment is also as a process in order to provide power to powerless people and reduce power of parties who are very powerful. Similarly, empowerment is where people, organizations and communities are directed to be able to control or rule over their lives (Bartlett, 2008). Understanding empowerment emphasizes the aspect of the delegation of power, giving authority or transfer of power to individuals or society, so as to manage themselves and the environment in accordance with their desires, potential and ability.

The purpose of empowerment has various ways (Wilkinson, 1998). For instance, first is to improve understanding and knowledge through better education. Thus, empowerment should be designed as a form of better education. Improving education through empowerment is not only to material improvements, method improvements, time and time improvements, and facilitator and beneficiary relationships, but also to foster a lifelong learning spirit; second is to improve accessibility, meaning that with the growth and development of the spirit of lifelong learning, it is expected to improve accessibility, especially accessibility to sources of information/innovation, to sources of financing, to providers of products and equipment, as well as to marketing institutions; third is to have better action. This means that when there are good and improved education and accessibility with better resources, then there is an expectation of better actions; fourth is to have better institutions. This means that when there is the improvement of activities/actions undertaken, then it is expected to improve institutions, including the development of business-partnership networks; fifth is to have better business improvement, meaning that improvement on education such as on the spirit of learning, accessibility, activities and institutional improvement should be followed by the improvement of business undertaken; sixth is to have better income which means that with the occurrence of business improvements made, it is expected to improve income earned, including family and community income; seventh is to improve the environment. This means that income improvement is also expected to improve the environment both physical and social. The reason is that environmental damage is often caused by poverty or limited income; eight is to have better living. Once the level of income and improved environmental are achieved, the living conditions of every family and community is expected to thrive; ninth is to have beeter community. Better living condition which is supported by physical and social environment is expected to manifest better community life.

In terms of strategy for community empowerment, this study considers the People Centered Development approach (see Dasgupta and Beard, 2007). The approach recognizes the importance of the capacity of the community in enhancing self-reliance and internal power through the ability to exercise internal control over material and non-material resources through capital or ownership levies. Key strategies for community empowerment include: (a) strengthening access to law, information and economy; (b) reinforcing rights to access coastal tourist areas, right of use for withadrawal and right of management, (c) institutional strengthening to determine the direction of community empowerment policies in natural resource management and the environment covering such as social values, norms, players of the game, control, incentives, and needs (Hales, 2010; Bartlett, 2008). Community empowerment is not only to develop the economic potential of people, but also to improve dignity, self-esteem, as well as maintaining the local culture and values. In order to achieve the community empowerment, continuous strategic studies on the restructuring of social systems at micro, mezzo and macro levels are required (Hales, 2010). This is intended to enable local communities to develop their potential without experiencing external barriers to mezzo and macro structures. 
Mezzo structure can be a regional government structure at the level of regency, city and province. The macro structure can be a central and national government structure (Wilkinson, 1998). The empowerment process is aimed to assist clients to gain power in making decisions, determining actions and self-control including reducing the effects of personal and social barriers in taking action. All these require ability and confidence in using power owned through the transfer of power and the support from the environment. In the implementation of empowerment program, it is necessary to have cooperation among various parties such as local governments, communities and social institutions that exist in the community. Harmonious, balanced and mutually beneficial cooperation will maintain the sustainability of the development program in order to achieve prosperity.

\section{METHODS OF RESEARCH}

This research was conducted based through fieldwork and laboratory activities. Data was collected from a case study which was Tanggamus Regency at Forestry Office and the community forestry in the regency area of 30 Tanggamus Mountain, Pekon Teratas, Kota Agung Utara District, Tanggamus Regency. Laboratory studies were conducted in the form of Focus Group Discussion (FGD) activities with other relevant researchers in the area of community empowerment. Qualitative approach through a case study was used with descriptive research type (Stake, 1995). In accordance with the research objectives, numbers of informants were interviewed such as local governments as policy makers and local communities, especially community forest, field facilitators in the implementation of policy utilization of community forestry programs in the region 30 Tanggamus Regency (Pekon Teratas). Primary data was obtained through key informants who are competent were chosen purposively. They are the Head of Forestry Service of Regency of Tanggamus, Head of Forest Management Division of Forestry Service of Tanggamus, Forest Community Association at Kota Agung Utara Tanggamus, Chairman of the Forest Protection Management and Conservation Group of Tanggamus Regency. Secondary data is also used documents, regulations and archives relating to the substance / research study. Data collection was done using research instrument through observation including supporting devices, recorder, interview guide, notes, pencils, and cameras (Silverman, 2012; Arksey and Knight, 1999). Data analysis was carried out through qualitative approach. To determine the validity of data, this study used 4 criteria, namely, credibility, transferability, dependability, and confirmability. To examine credibility, triangulation was used and analyzed through matching the patterns and trends of information that have been collected and used as a comparison material.

\section{RESULTS AND DISCUSSION}

Policy on the Development of Forestry and Estate Crops in Tanggamus Regency consists of improving the quality of apparatus resources, improving forest and land rehabilitation, enhancing the forest law enforcement and security, increasing the utilization of forest resources, increasing productivity of plantation enterprises through plantation development and agribusiness of plantation, increasing the value of plantation business products through improvement processed quality, market access, technology development and partnership development between the private sector, the government and the community.

Community Forest Policy. The community forest policy was issued in 1995 through the issuance of the Decree of the Minister of Forestry No. 622/Kpts-II/1995. Following the Director General of Forest Utilization is supported by Non-governmental Organizations, Universities and International Agencies, designing pilot projects in various places for forest concession management involving local communities. In 2007, there was national declaration of community forest as one of community empowerment pattern, besides people forest plantation and village forest. Community forest is a state forest whose main use is to empower local people. Community forests are expected to enhance the capability and 
independence of local communities so that they can benefit from forest resources optimally and fairly through capacity building and access provision in order to improve the welfare of the local people in protected forest areas. The provision is that forests are not burdened with rights or permits for the utilization of forest products and become the source of local livelihoods. Permit for the utilization of Community Forest is granted for 35 years and can be extended according to the evaluation result in every 5 years. Community forests are for poor people at local communities who live in and around the forest and they rely on livelihoods from utilizing forest resources (Bartlett, 2008).

Communities which implement community forest policies may comply with required provisions. Community forests are not only as implementers of forest savings programs, but also as a way of learning. Community forestry programs can be a way to achieve sustainable development objectives. Constraints in the implementation of community forest policy are lack of community resources, facilitators and funding. These constraints will always exist in every strategy of implementing a development program, including community forest policy.

Table 2 - List of Working Area of Community Forestry in Tanggamus Regency

\begin{tabular}{|l|l|l|l|l|l|}
\hline No & Location & Name of Group & Area & $\begin{array}{l}\text { Number of Letters from } \\
\text { the Minister of Forestry }\end{array}$ & Number of Permit \\
\hline & $\begin{array}{l}\text { Tanggamus } \\
\text { Regency }\end{array}$ & - & $2.547,22$ & - & - \\
\hline 1 & $\begin{array}{l}\text { Datarajan Village, } \\
\text { Ulu Belu District }\end{array}$ & KPPM & 593,58 & $\begin{array}{l}\text { SK 433/Menhut-II/2007 } \\
10 \text { Des 2007 }\end{array}$ & B.333/23/03/2007/12/2007 \\
\hline 2 & $\begin{array}{l}\text { Payung Village, } \\
\text { Kota Agung District }\end{array}$ & $\begin{array}{l}\text { Koperasi } \\
\text { Sumber Rejeki }\end{array}$ & 499,56 & $\begin{array}{l}\text { SK 433/Menhut- } \\
\text { II/2007/10 Des 2007 }\end{array}$ & $\begin{array}{l}\text { B.334/23/03/2007/12/2007 } \\
\text { Date 01/12/2007 }\end{array}$ \\
\hline 3 & $\begin{array}{l}\text { Datarajan Village } \\
\text { Ulu Belu District }\end{array}$ & $\begin{array}{l}\text { Koperasi } \\
\text { Harapan } \\
\text { Sentosa }\end{array}$ & 300 & $\begin{array}{l}\text { SK 433/Menhut-II/2007 } \\
10 \text { Des 2007 }\end{array}$ & $\begin{array}{l}\text { B.335/23/03/2007/12/2007 } \\
\text { Desember 2007 }\end{array}$ \\
\hline 4 & $\begin{array}{l}\text { Napal Village, } \\
\text { Bulok District }\end{array}$ & Gapoktan Hkm & 475,71 & $\begin{array}{l}\text { SK 433/Menhut-II/2007 } \\
10 \text { Des 2007 }\end{array}$ & $\begin{array}{l}\text { B336/23/03/2007/12/2007 } \\
\text { Date 01/12/2007 }\end{array}$ \\
\hline
\end{tabular}

Source: Forestry Office department in Lampung Province.

The Implementation of Community Forestry in Tanggamus Regency. The Community Forest policy was enacted in the 1990s and it was implemented massively since in 2007. Community Forest is one of community empowerment patterns along with the Community Forest Plantation, Village Forest and Partnership Scheme. In several locations in Lampung Province, the implementation of community forest shows that the pattern of the arrangement is well developed, acceptable and carried out by both the government and the community. Community Forests as state forests which its main purpose is intended to empower and improve the welfare of local communities through the utilization of forest resources in optimal ways, fairly, and sustainable manner with keeping sustainability of forest functions. In addition, community forestry program is one of the efforts to save forests while providing benefits to the community through Community Based Natural Resource Management. Groups of communities are granted rights to access and manage forest resources. In this context, the role of field facilitators resides and settles in villages directly located in forest areas. They conduct discussions/FGDs and learn together with communities in order to manage forests properly. Community forests are intended for capacity building and for providing access to local communities in order to manage forests sustainably as well as to ensure employment availability for communities.

In solving the economic and social problems which exist in the community, it is needed the commitment of parties/stakeholders. It also needs to implementat community forestry program in the community. Communities conducting community forestry programs may comply with required provisions. The community is not only developed as a forest saving program, but also as a way for learning process. Thus, community forest programs can be a means to achieve Sustainable Development Goals (SDGs). In general, there are several constraints in implementing community forestry programs. They are availability of funding and the funding schemes as well as capacity gaps in community resources, facilitators and 
the local government. These constraints will always exist in every stage and strategy for implementing development programs, such as community forestry programs. But, there is a positive outcome if the community forestry programs can be a way to strength and to build the capacity, empowe community potential.

The basic policy of the implementation of community forest in Tanggamus Regency refers to the law and legal products related to community forest, namely:

Table 3 - Legal Products Related to Community Forest

\begin{tabular}{|c|c|c|}
\hline No & Legal Products & Remarks \\
\hline 1. & UU RI No. 5 Year 1990 & Conservation of Biological Natural Resources and its Ecosystem \\
\hline 2. & Kep Menhut No. 622 Year 1995 & Community Forest Guidelines \\
\hline 3. & UU RI No. 23 Year 1997 & Environmental Management \\
\hline 4. & SK Menhut No.677/Kpts-II/1998 & Community Forest \\
\hline 5. & UU RI No. 41 Year 1999 & Forestry \\
\hline 6. & SK Menhut No.865/1999 & Utilization of State Forest \\
\hline 7. & SK Menhut No. 31/2001 & Community Forest \\
\hline 8. & UU RI No. 44 Year 2004 & Forest Planning \\
\hline 9. & PP Menhut No.34 Year 2002 & $\begin{array}{l}\text { Forest Administration, Forest Management Plan, Forest Utilization } \\
\text { and Forestry Utilization Forest }\end{array}$ \\
\hline 10 & PP Menhut No. 6 Year 2007 & $\begin{array}{l}\text { Forest Administration, Forest Management Plan, Forest Utilization } \\
\text { and Forestry Utilization Forest }\end{array}$ \\
\hline 11 & PP Menhut No. P.37/ Year 2007 & Community Forest \\
\hline 12 & PP Menhut RI No.P.13/Menhut-II/2010 & $\begin{array}{l}\text { Third Amendment to Regulation of the Minister of Forestry } \\
\text { Number .37/Menhut-II/2007 on Community Forest }\end{array}$ \\
\hline 13 & $\begin{array}{l}\text { The Minister of Forestry Decree Republik } \\
\text { Indonesia No. P.52/Menhut-II/2011 }\end{array}$ & $\begin{array}{l}\text { Third Amendment to Regulation of the Minister of Forestry Numbe } \\
\text { P.37/Menhut-II/2007 on Community Forest }\end{array}$ \\
\hline 14 & $\begin{array}{l}\text { Tanggamus Mayor Decree } \\
\text { No.B.334/23/03/2007 }\end{array}$ & $\begin{array}{l}\text { Granting of Business License of Community Forest Utilization } \\
\text { (IUPHKm) to cooperative of Sumber Rejeki, Pekon Payung }\end{array}$ \\
\hline 15 & $\begin{array}{l}\text { Decree of Tanggamus Mayor } \\
\text { No.B.335/23/03/2007 }\end{array}$ & $\begin{array}{l}\text { Granting of Business License of Community Forest Utilization } \\
\text { (IUPHKm) to Kelompok Hutan Kemasyarakatan (KPPM) Pekon } \\
\text { Datarajan, Ulu Belu District }\end{array}$ \\
\hline 16 & $\begin{array}{l}\text { Decree of Bupati Tanggamus } \\
\text { No.B.264/39/12/2009 }\end{array}$ & $\begin{array}{l}\text { Granting of Business License of Community Forest Utilization } \\
\text { (IUPHKm) to farmer group of Tani Margo Rukun }\end{array}$ \\
\hline 17 & $\begin{array}{l}\text { Decree of Bupati Tanggamus } \\
\text { No.B.263/39/12/2009 }\end{array}$ & $\begin{array}{l}\text { Granting of Business License of Community Forest Utilization } \\
\text { (IUPHKm) to farmer group of Tani Tunas Muda }\end{array}$ \\
\hline 18 & $\begin{array}{l}\text { Decree of Bupati Tanggamus } \\
\text { No.B.262/39/12/2009 }\end{array}$ & $\begin{array}{l}\text { Granting of Business License of Community Forest Utilization } \\
\text { (IUPHKm) to Farmer Group of Mandiri Lestari }\end{array}$ \\
\hline 19 & $\begin{array}{l}\text { Decree of Bupati Tanggamus } \\
\text { No.B.260/39/12/2009 }\end{array}$ & $\begin{array}{l}\text { Granting of Business License of Community Forest Utilization } \\
\text { (IUPHKm) to Farmer Group of Tani Hijau Makmur }\end{array}$ \\
\hline 20 & $\begin{array}{l}\text { Decree of Bupati Tanggamus } \\
\text { No.B.265/39/12/2009 }\end{array}$ & $\begin{array}{l}\text { Granting of Business License of Community Forest Utilization } \\
\text { (IUPHKm) to farmer group of Tani Bina Wana Jaya II }\end{array}$ \\
\hline 21 & $\begin{array}{l}\text { Decree of Bupati Tanggamus } \\
\text { No.B.266/39/12/2009 }\end{array}$ & $\begin{array}{l}\text { Granting of Business License of Community Forest Utilization } \\
\text { (IUPHKm) to farmer group of Bina Wana Jaya I }\end{array}$ \\
\hline 22 & $\begin{array}{l}\text { Decree of the Minister of Forestry No. } \\
886 / \text { Menhut-II/2013 }\end{array}$ & $\begin{array}{l}\text { Determination of working area Hkm Gapoktan Beringin Raya } \\
\text { Pekon Talang Berir, Pulau Panggung District Reg } 30\end{array}$ \\
\hline 23 & $\begin{array}{l}\text { Decree of the Minister of Forestry } \\
\text { No. } 886 / \text { Menhut-II/2013 }\end{array}$ & $\begin{array}{l}\text { Determination of working area Hkm Reg } 30 \text { Gapoktan Mulya } \\
\text { Agung, Pekon Sidomulyo Semaka District }\end{array}$ \\
\hline 24 & $\begin{array}{l}\text { Decree of the Minister of Forestry } \\
\text { No. 886/Menhut-II/2013 }\end{array}$ & Gapoktan Tulung Agung, Pekon Talang Asah Semaka District \\
\hline 25 & $\begin{array}{l}\text { Decree of the Minister of Forestry } \\
\text { No. 886/Menhut-II/2013 }\end{array}$ & $\begin{array}{l}\text { Gapoktan Hutan Lestari Pekon Gunung Doh, Bandar Negeri } \\
\text { Semuong District }\end{array}$ \\
\hline 26 & $\begin{array}{l}\text { Decree of the Minister of Forestry } \\
\text { No. } 886 / \text { Menhut-II/2013 }\end{array}$ & $\begin{array}{l}\text { Gapoktan Tunas Jaya Pekon Atar Lebar Bandar Negeri Semuong } \\
\text { District }\end{array}$ \\
\hline 27 & $\begin{array}{l}\text { Decree of the Minister of Forestry } \\
\text { No. } 886 / \text { Menhut-II/2013 }\end{array}$ & Gapoktan Bakti Mandiri, Ulu Belu District \\
\hline 28 & $\begin{array}{l}\text { Decree of the Minister of Forestry } \\
\text { No. } 886 / \text { Menhut-II/2013 }\end{array}$ & Gapoktan Wana Binangkit, Kota Agung Barat \\
\hline 29 & $\begin{array}{l}\text { Decree of the Minister of Forestry No. } \\
886 / \text { Menhut-II/2013 }\end{array}$ & Gapoktan Sinar Mulya, Ulu Belu District \\
\hline 30 & $\begin{array}{l}\text { Decree of the Minister of Forestry } \\
\text { No. } 886 / \text { Menhut-II/2013 }\end{array}$ & Gapoktan Rimba Jaya, Ulu Belu District \\
\hline 31 & $\begin{array}{l}\text { Decree of the Minister of Forestry } \\
\text { No. } 886 / \text { Menhut-II/2013 }\end{array}$ & $\begin{array}{l}\text { Gapoktan Sumber Makmur } \\
\text { Ulu Belu District Register } 30\end{array}$ \\
\hline
\end{tabular}


Table 4 - List of Farmer Groups of Community Forest in Tanggamus Regency, 2007-2010

\begin{tabular}{|l|l|l|l|l|l|}
\hline No & Year & Number of Groups & Number of Household & Size of Area $(\mathrm{Ha})$ & Permit Status \\
\hline 1. & 1999 & 1 & 200 & 400 & Temporary \\
\hline 2. & 2007 & 5 & 2.015 & 2.570 & Permanent \\
\hline 3 & 2008 & 9 & - & $12.905,05$ & In the Process of Submission \\
\hline 4. & 2010 & 14 & 23.000 & $12.061,30$ & Waiting for Approval \\
\hline
\end{tabular}

Table 5 - List of Community Forest Groups at the area of Forest in Tanggamus Regency, especially at Kota Agung Utara and Tanggamus Mountain

\begin{tabular}{|c|c|c|c|c|c|}
\hline No & Group Name & Letter of Decision & $\begin{array}{l}\text { Number of } \\
\text { Groups }\end{array}$ & $\begin{array}{l}\text { Size of } \\
\text { Area, ha }\end{array}$ & Remarks \\
\hline 1 & $\begin{array}{l}\text { KPPM Pekon Dataraja, } \\
\text { Ulu Belu District Reg } 30 \\
\text { and } 32\end{array}$ & $\begin{array}{l}\text { SK.B.313/KWL 4/Kpts } \\
2000 \\
\text { SK Tanggamus Regent } \\
\text { No. 333/23/03/2007 } \\
\end{array}$ & $\begin{array}{l}11 \text { Groups } \\
33 \mathrm{KK}\end{array}$ & 593,58 & $\begin{array}{l}\text { Permanent Permit for } \\
35 \text { Years }\end{array}$ \\
\hline 2 & $\begin{array}{l}\text { Harapan Sentosa Farmer } \\
\text { Groups }\end{array}$ & $\begin{array}{l}\text { SKB } \\
\text { 162/Hutbun/Hk/2001 }\end{array}$ & $\begin{array}{l}9 \text { Groups } \\
273 \mathrm{KK}\end{array}$ & 300,00 & $\begin{array}{l}\text { Permanent Permit for } \\
35 \text { Years }\end{array}$ \\
\hline 3 & $\begin{array}{l}\text { Farmer Groupf of Sumber } \\
\text { Rejeki Pekon Payung, } \\
\text { Kota Agung District Reg } \\
30\end{array}$ & $\begin{array}{l}\text { SKB } \\
434 / K W L .4 / K p t s / 2001 \\
\text { No B.334/23/03/2007 }\end{array}$ & $\begin{array}{l}7 \text { Groups } \\
275 \mathrm{KK}\end{array}$ & 499,56 & $\begin{array}{l}\text { Permanent Permit for } \\
35 \text { Years }\end{array}$ \\
\hline 4 & $\begin{array}{l}\text { Kop Bun Margo Rukun } \\
\text { Pekon Ngari, Ulu Belu } \\
\text { District }\end{array}$ & $\begin{array}{l}\text { SKB.264/Hutbun/39/12/2 } \\
009\end{array}$ & $\begin{array}{l}6 \text { Groups } \\
282 \mathrm{KK}\end{array}$ & 1428,70 & $\begin{array}{l}\text { Permanent Permit for } \\
35 \text { Years }\end{array}$ \\
\hline 5 & $\begin{array}{l}\text { Gapoktan Bhakti Makmur } \\
\text { Pekon Teratas, Kota } \\
\text { Agung District reg } 30 \\
\end{array}$ & SK.B.259/39/2009 & $\begin{array}{l}11 \text { Groups } \\
565 \mathrm{KK}\end{array}$ & 856,60 & $\begin{array}{l}\text { Permanent Permit for } \\
35 \text { Years }\end{array}$ \\
\hline 6 & $\begin{array}{l}\text { Gapoktan Karya Tani } \\
\text { Pekon Penantian Ulu Belu } \\
\text { Reg } 39 \text { dan } 32\end{array}$ & SK B.261/39/12/2009 & $653 \mathrm{KK}$ & $1.977,60$ & $\begin{array}{l}\text { Permanent Permit for } \\
35 \text { Years }\end{array}$ \\
\hline 7 & $\begin{array}{l}\text { Gapoktan Beringin Raya } \\
\text { Pekon Talang Berir, Pulau } \\
\text { Panggung District Reg } 30\end{array}$ & No. 886/Menhut-II/2013 & $446 \mathrm{KK}$ & 907,78 & $\begin{array}{l}\text { Determining working } \\
\text { area of community } \\
\text { forest }\end{array}$ \\
\hline 8 & $\begin{array}{l}\text { Gapoktan Mulya Agung } \\
\text { Pekon Sidomulyo, } \\
\text { Semaka District }\end{array}$ & No. 886/Menhut-II/2013 & $961 \mathrm{KK}$ & 1662,64 & $\begin{array}{l}\text { Determining working } \\
\text { area of community } \\
\text { forest Reg } 39\end{array}$ \\
\hline 9 & $\begin{array}{l}\text { Gapoktan Tulung Agung } \\
\text { Pekon Talang Asah, } \\
\text { Semaka District }\end{array}$ & No. 882/Menhut-II/2013 & $926 \mathrm{KK}$ & $1.046,73$ & $\begin{array}{l}\text { Determining working } \\
\text { area of community } \\
\text { forest Reg } 39\end{array}$ \\
\hline 10 & $\begin{array}{l}\text { Gapoktan Hutan Lestari } \\
\text { Pekon Gunung Doh, } \\
\text { Bandar Negeri Semuong } \\
\text { District }\end{array}$ & No. 885/Menhut-II/2013 & 171 & 385,11 & $\begin{array}{l}\text { Determining working } \\
\text { area of community } \\
\text { forest Reg } 39\end{array}$ \\
\hline 11 & $\begin{array}{l}\text { Gapoktan Tunas Jaya } \\
\text { Pekon Atar Lebar, Bandar } \\
\text { Negeri Semuong District }\end{array}$ & No. 889/Menhut-II/2013 & 584 & 1264,72 & $\begin{array}{l}\text { Determining working } \\
\text { area of community } \\
\text { forest Reg } 39\end{array}$ \\
\hline 12 & $\begin{array}{l}\text { Gapoktan Bakti Mandiri, } \\
\text { Ulu Belu Distrcit }\end{array}$ & No. 884/Menhut-II/2013 & 421 & 563,75 & $\begin{array}{l}\text { Determining working } \\
\text { area of community } \\
\text { forest Reg } 39\end{array}$ \\
\hline 13 & $\begin{array}{l}\text { Gapoktan Wana } \\
\text { Binangkit, Kota Agung } \\
\text { Barat District }\end{array}$ & No. 81/Menhut-II/2013 & 217 & 289.14 & $\begin{array}{l}\text { Determining working } \\
\text { area of community } \\
\text { forest Reg } 30\end{array}$ \\
\hline 14 & $\begin{array}{l}\text { Gapoktan Sinar Mulya, } \\
\text { Ulu Belu District }\end{array}$ & No. 80/Menhut-II/2013 & 701 & 1.013 & $\begin{array}{l}\text { Determining working } \\
\text { area of community } \\
\text { forest Reg } 39\end{array}$ \\
\hline 15 & $\begin{array}{l}\text { Gapoktan Rimba Jaya } \\
\text { Kec Ulu Belu }\end{array}$ & - & 832 & 1600,00 & $\begin{array}{l}\text { Implementation, } \\
\text { Measurement and } \\
\text { Preparing Proposal }\end{array}$ \\
\hline 16 & $\begin{array}{l}\text { Gapoktan Sumber } \\
\text { Makmur } \\
\text { Kec Ulu Belu } \\
\text { Reg } 30\end{array}$ & - & 550 & 1300,00 & $\begin{array}{l}\text { Implementation, } \\
\text { Measurement and } \\
\text { Preparing Proposal }\end{array}$ \\
\hline
\end{tabular}


Table 6 - List of Community Forest Farmer Groups Holding Permanent Permits in Tanggamus Regency in 2014

\begin{tabular}{|c|c|c|c|c|c|}
\hline No & Group Name & Letter of Decision & $\begin{array}{l}\text { Number of } \\
\text { Household }\end{array}$ & $\begin{array}{l}\text { Size } \\
\text { (ha) }\end{array}$ & Remarks \\
\hline 1 & $\begin{array}{l}\text { Gapoktan } \\
\text { Sidodadi }\end{array}$ & $\begin{array}{l}\text { No.8.464/34/II/2014 } \\
\text { Tgl. } 30-12-2-14\end{array}$ & 391 & 2,306 & $\begin{array}{l}\text { Permit from the Tanggamus } \\
\text { Regent }\end{array}$ \\
\hline 2 & $\begin{array}{l}\text { Gapoktan Sinar } \\
\text { Harapan }\end{array}$ & $\begin{array}{l}\text { No.B.467/34/l//2014 Tgl. } \\
\text { 30-12-2014 }\end{array}$ & 468 & 4,834 & $\begin{array}{l}\text { Permit from the Tanggamus } \\
\text { Regent }\end{array}$ \\
\hline 3 & $\begin{array}{l}\text { Gapoktan } \\
\text { Kelumbayan Maju }\end{array}$ & $\begin{array}{l}\text { No.B.462/34/II/2014 Tgl. } \\
\text { 30-12-2014 }\end{array}$ & 802 & 1,910 & $\begin{array}{l}\text { Permit from the Tanggamus } \\
\text { Regent }\end{array}$ \\
\hline 4 & $\begin{array}{l}\text { Gapoktan Lestari } \\
\text { Jaya }\end{array}$ & $\begin{array}{l}\text { No.B.472/34/I//2014 Tgl. } \\
\text { 30-12-2014 }\end{array}$ & 556 & 665 & $\begin{array}{l}\text { Permit from the Tanggamus } \\
\text { Regent }\end{array}$ \\
\hline 5 & $\begin{array}{l}\text { Gapoktan Beringin } \\
\text { Jaya }\end{array}$ & $\begin{array}{l}\text { No.B.465/34/ll/2014 Tgl. } \\
\text { 30-12-2014 }\end{array}$ & 331 & 871 & $\begin{array}{l}\text { Permit from the Tanggamus } \\
\text { Regent }\end{array}$ \\
\hline 6 & $\begin{array}{l}\text { Gapoktan Wira } \\
\text { Karya Sejahtera }\end{array}$ & $\begin{array}{l}\text { No.B.466/34/ll/2014 Tgl. } \\
\text { 30-12-2014 }\end{array}$ & 904 & 4,305 & $\begin{array}{l}\text { Permit from the Tanggamus } \\
\text { Regent }\end{array}$ \\
\hline 7 & $\begin{array}{l}\text { Gapoktan Mulya } \\
\text { Agung }\end{array}$ & $\begin{array}{l}\text { No.B.459/34/ll/2014 Tgl. } \\
\text { 30-12-2014 }\end{array}$ & 961 & 1,473 & $\begin{array}{l}\text { Permit from the Tanggamus } \\
\text { Regent }\end{array}$ \\
\hline 8 & $\begin{array}{l}\text { Gapoktan Tulung } \\
\text { Agung }\end{array}$ & $\begin{array}{l}\text { No.B.463/34/ll/2014 Tgl. } \\
\text { 30-12-2014 }\end{array}$ & 844 & 902 & $\begin{array}{l}\text { Permit from the Tanggamus } \\
\text { Regent }\end{array}$ \\
\hline 9 & $\begin{array}{l}\text { Gapoktan Karya } \\
\text { Tani Sejahtera }\end{array}$ & $\begin{array}{l}\text { No.B.470/34/ll/2014 Tgl. } \\
\text { 30-12-2014 }\end{array}$ & 995 & 3,382 & $\begin{array}{l}\text { Permit from the Tanggamus } \\
\text { Regent }\end{array}$ \\
\hline 10 & $\begin{array}{l}\text { Gapoktan Hutan } \\
\text { Lestari }\end{array}$ & $\begin{array}{l}\text { No.B.475/34/II/2014 Tgl. } \\
\text { 30-12-2014 }\end{array}$ & 171 & 382 & $\begin{array}{l}\text { Permit from the Tanggamus } \\
\text { Regent }\end{array}$ \\
\hline 11 & $\begin{array}{l}\text { Gapoktan Tunas } \\
\text { Jaya }\end{array}$ & $\begin{array}{l}\text { No.B.474/34/ll/2014 Tgl. } \\
\text { 30-12-2014 }\end{array}$ & 584 & 1,388 & $\begin{array}{l}\text { Permit from the Tanggamus } \\
\text { Regent }\end{array}$ \\
\hline 12 & $\begin{array}{l}\text { Gapoktan Bakti } \\
\text { Mandiri }\end{array}$ & $\begin{array}{l}\text { No.B.476/34/II/2014 Tgl. } \\
\text { 30-12-2014 }\end{array}$ & 421 & 473 & $\begin{array}{l}\text { Permit from the Tanggamus } \\
\text { Regent }\end{array}$ \\
\hline 13 & $\begin{array}{l}\text { Gapoktan Wana } \\
\text { Jaya }\end{array}$ & $\begin{array}{l}\text { No.B.471/34/II/2014 Tgl. } \\
\text { 30-12-2014 }\end{array}$ & 801 & 1,507 & $\begin{array}{l}\text { Permit from the Tanggamus } \\
\text { Regent }\end{array}$ \\
\hline 14 & $\begin{array}{l}\text { Gapoktan Sinar } \\
\text { Mulya }\end{array}$ & $\begin{array}{l}\text { No.B.461/34/II/2014 Tgl. } \\
\text { 30-12-2014 }\end{array}$ & 263 & 917 & $\begin{array}{l}\text { Permit from the Tanggamus } \\
\text { Regent }\end{array}$ \\
\hline 15 & $\begin{array}{l}\text { Gapoktan } \\
\text { Mahrdika }\end{array}$ & $\begin{array}{l}\text { No.B.468/34/II/2014 Tgl. } \\
\text { 30-12-2014 }\end{array}$ & 1,141 & 2,340 & $\begin{array}{l}\text { Permit from the Tanggamus } \\
\text { Regent }\end{array}$ \\
\hline 16 & $\begin{array}{l}\text { Gapoktan Kuyung } \\
\text { Jaya }\end{array}$ & $\begin{array}{l}\text { No.B.469/34/ll/2014 Tgl. } \\
\text { 30-12-2014 }\end{array}$ & 1,044 & 1,514 & $\begin{array}{l}\text { Permit from the Tanggamus } \\
\text { Regent }\end{array}$ \\
\hline 17 & $\begin{array}{l}\text { Gapoktan Wana } \\
\text { Binangkit }\end{array}$ & $\begin{array}{l}\text { No.B.473/34/ll/2014 Tgl. } \\
\text { 30-12-2014 }\end{array}$ & 106 & 288 & $\begin{array}{l}\text { Permit from the Tanggamus } \\
\text { Regent }\end{array}$ \\
\hline 18 & $\begin{array}{l}\text { Gapoktan Maju } \\
\text { Jaya }\end{array}$ & $\begin{array}{l}\text { No.B.460/34/I/l/2014 Tgl. } \\
\text { 30-12-2014 }\end{array}$ & 265 & 887 & $\begin{array}{l}\text { Permit from the Tanggamus } \\
\text { Regent }\end{array}$ \\
\hline 19 & $\begin{array}{l}\text { Gapoktan Rimba } \\
\text { Jaya }\end{array}$ & (a) & 832 & 1,600 & $\begin{array}{l}\text { Implementation, } \\
\text { Measurement and Preparing } \\
\text { Proposal }\end{array}$ \\
\hline 20 & Sumber Abadi & - & - & 550 & $\begin{array}{l}\text { Implementation, } \\
\text { Measurement and Preparing } \\
\text { Proposal }\end{array}$ \\
\hline 21 & Wana Arba Lestari & - & - & 1,000 & $\begin{array}{l}\text { Implementation, } \\
\text { Measurement and Preparing } \\
\text { Proposal }\end{array}$ \\
\hline 22 & Wana Tani Lestari & - & 483 & 3,091 & $\begin{array}{l}\text { Implementation, } \\
\text { Measurement and Preparing } \\
\text { Proposal }\end{array}$ \\
\hline 23 & Sinar Petir & - & - & - & $\begin{array}{l}\text { Implementation, } \\
\text { Measurement and Preparing } \\
\text { Proposal }\end{array}$ \\
\hline 24 & Trisno Wana Jaya & - & 482 & $1,081,90$ & $\begin{array}{l}\text { Implementation, } \\
\text { Measurement and Preparing } \\
\text { Proposal }\end{array}$ \\
\hline 25 & Citra Lestari & - & 694 & 955 & $\begin{array}{l}\text { Implementation, } \\
\text { Measurement and Preparing } \\
\text { Proposal }\end{array}$ \\
\hline 26 & Wana Jaya & - & 489 & 679 & $\begin{array}{l}\text { Implementation, } \\
\text { Measurement and Preparing } \\
\text { Proposal }\end{array}$ \\
\hline
\end{tabular}


Based on table 4, Tanggamus Regency submitted a proposal for community forest of 9 farmer groups with a total area of 12,905.05 hectares located in protected forest area register 21 , register 27, register 30, register 32 and register 39 to the Ministry of Forestry in 2008 in accordance with the Decree of the Regent of Tanggamus Regency Number: 522/4111/39 dated 14 July 2008. Of the 9 Community Forest Groups proposed permission and then in 2009, 8 groups have been verified by the Ministry of Forestry with an area of 10,781 hectares. The Bakti Makmur Farmers Group in Pekon Teratas, Kota Agung District at Tanggamus Regency is applying for Community Forest Management Permit to the Forestry and Plantation Office of Tanggamus Regency. In 2010, there have been 14 community forestry farmer groups in Tanggamus Regency which have obtained the community forest management license, while 6 farmer groups are still in the process of applying for community forest management permit. The Minister of Forestry of the Republic of Indonesia, Mr Zulkifli Hasan on 22 April 2010 enacted the Decree of the Minister of Forestry of the Republic of Indonesia Number 751/Menhut-II/2009 which stipulates the Forest Zone as a Community Forest Working Area, in Tanggamus Regency of 12,061.30 hectares. The other 2 Farmer Group, namely Rimba Jaya in Ulu Belu District and Sumber Makmur at Ulu Belu District Register 30 implemented the measurement and preparation of proposal. Furthermore, in 2013, there are 8 Farmer Groups received licence of community forest management. All data can be seen in Table 5 .

While two other farmer groups, namely Rimba Jaya at Ulu Belu District and Sumber Makmur at Ulu Belu Register 30, conduct the implementation of measurement and preparation proposal.

Cooperation between Government and Society for Community Forest Management Policy. Increase in number of community participations in both forest policy and management can prevent and mitigate forest destruction. The current forestry policy provides real opportunities for communities within and around forest areas. Community forestry policy allows communities to manage some of the forest resources. An effort for community involvement is carried out through strengthening community forest management institutions by establishing a forest management organization which has: (1) internal binding group rules in decision making, conflict resolution and other rules in organizational management; (2) rules in forest management; (3) recognition from the community through the Village; and (4) plan of location and area of work and management period. Facilitation to groups of community forestry farmers in preparing the Community Forestry Work Plan has been implemented in Tanggamus District. The activity was facilitated by the Ministry of Forestry of the Republic of Indonesia, the Unitary Forest Management Unit at Lampung Province.

Community Forest Policy. As mentioned above, community forest policy was initially issued in 1995 through the issuance of Forestry Ministerial Decree No. 622/Kpts-II /1995 followed by the Director General of Forest Utilization which is supported by NonGovernmental Organizations, Universities, and international agencies, designing pilot projects. All stakeholders contribute in various places regarding forest concession management involving local communities. In 2007, there was the year of national declaration for community forest which is one of community empowerment pattern along with community plantation forest and village forest. Community forest is a state forest in order to empower local people, expected to enhance the capability and independence of local communities so that they can benefit from forest resources optimally and fairly through capacity building and giving access provision in order to improve the welfare of local communities. Community forest only applies in protected forest areas and in production forests. The provision is that forests are not burdened with rights or permits for the utilization of forest products and the forests become source of local livelihoods. Permit for community forest utilization is granted for 35 year period and can be extended according to the evaluation result every 5 years. Community forests are dedicated to the local poor who live in and around the forest which thay rely on livelihoods from the use of forest resources. Communities which implement community forest policies may comply with required provisions. Community forests are not only developed as implementers of forest savings programs, but also to be a means of learning process. Furthermore, community forestry programs can be a means to achieve 
sustainable development objectives. There are constraints or limitations in the implementation of community forest policies where there lack of community resources, facilitators and funding. However, constraints and limitations will always exist in every stage of strategy for implementing a development program including community forest policy.

\section{CONCLUSION AND RECOMMENDATIONS}

This research concludes that the implementation of community forest policy in Tanggamus Regency is based on Forestry Minister Regulation No. 37 Year 2007 and its amendments, in conjunction with Minister of Forestry Regulation No P.88 / Menhut-II / 2014 on Community Forest and Ministry of Environment and Forestry Regulation of the Republic Indonesia Number P.83/MenLHK/Setjen/Kum.1/10/2016 on Social Forestry, namely by providing access to the community by involving communities to manage forests. The implementation of community forestry through empowerment activities undertaken cannot only be undertaken by forestry officers or Protected Forest Management Unity, but it also requires support and commitment of the parties in its implementation. The success rate of community forestry programs can be seen from the level of public awareness of forests, and public awareness in planting the plants that have been determined. Furthermore, several recommendations can be suggested as follows: first, constraints in the application of community forest management permits are a complex in the sense of bureaucracy, so that groups that will apply for community forest management permits are confused and lack the budget to apply for community forestry permits.Second, it, in the future very, needs to simplify the process of applying for community forest management permit, especially in the bureaucratic flow.

\section{REFERENCES}

1. Anwas, Oos M. 2014. Pemberdayaan Masyarakat di Era Global. ALFABETA. Bandung.

2. Arksey, H, and Knight, P. 1999. Interviewing for Social Scientists. Sage Publications. London, UK.

3. Bartlett, A. 2008. No more adoption rates! Looking for empowerment in agricultural development programmes. Development in Practice 18:4-5, 524-538.

4. Dasgupta, A, and Beard, A. V. (2007). Community Driven Development, Collective Action and Elite Capture in Indonesia. Development and Change, 38 (2): 229 -249.

5. Hales, C. 2000. Management and Empowerment Programmes. Work, Employment and Society 14:3, 501-519.

6. Hikmat, R. Harry. 2001. Strategi Pemberdayaan Masyarakat. Humaniora Utama Press (HUP).Bandung.

7. Irawan. Ade. 2014. Evaluasi Pelaksanaan Kebijakan Hutan Kemasyarakatan. Hasil Penelitian. Universitas Lampung.

8. Mardikanto, T., Poerwoko, S. 2015. Pemberdayaan Masyarakat. Bandung: ALFABETA.

9. Neta, Y. 2014. Model Pemberdayaan Masyarakat Lokal Dalam Pengembangan Hutan Kemasyarakatan Melalui Pengaturan Hak-Hak Atas Pengelolaan Dan Pemanfaatan Hutan Kemasyarakatan Di Kabupaten Tanggamus. Hasil Penelitian. Universitas Lampung.

10. Rahmat, S. 2005. Peluang dan Tantangan Pengelolaan Hutan Kemasyarakatan di Provinsi Lampung. Research Report, Buletin Kampung. Watala, Lampung.

11. Rosalia, F. 2016. Analisis Pengelolaan Hutan Kemasyarakatan di Sekitar Kawasan Hutan Lindung Register 30 Kabupaten Tanggamus Provinsi Lampung. Sosiohumaniora Unpad, Volume 18 No. 1: 32 - 36.

12. Silverman, D. 2012. Interpreting Qualitative Data. London: Sage Publications.

13. Sutaryono. 2008. Pemberdayaan Setengah Hati. Yopgyakarta: Lapera Pustaka Utama.

14. Wilkinson, A. 1998. Empowerment: theory and practice. Personnel Review, 27(1):40-56. 